Journal of The Indonesian Nutrition Association

p-ISSN: 0436-0265 e-ISSN: 2528-5874

http://ejournal.persagi.org/index.php/Gizi_Indon

\title{
OBESITAS SENTRAL PADA ORANG DEWASA: STUDI KOHOR PROSPEKTIF DI KOTA BOGOR
}

\section{Adults Central Obesity: A Prospective Cohort Study in Bogor City}

\author{
Sudikno, Woro Riyadina, Ekowati Rahajeng \\ Puslitbang Upaya Kesehatan Masyarakat, Badan Litbangkes \\ E-mail: onkidus@gmail.com
}

\begin{abstract}
Central obesity is one of the public health problems in developing countries. This study aims to analyze the dynamic risk factors for central obesity in adults. This study used secondary data "Cohort Study of Non-Communicable Diseases Risk Factors" observing period for six years. The study design was a prospective cohort. The subjects were all household members aged 25 years and above with the criteria remaining in the study area, healthy, non-physically disabled, non-pregnant, having normal abdominal circumference (male $\leq 90 \mathrm{~cm}$ and female $\leq 80 \mathrm{~cm}$ ) on baseline study, not suffering from noncommunicable diseases (hypertension, diabetes mellitus, cancer, stroke, chronic obstructive pulmonary disease) at the baseline of the study, and completeness of the data. The number of subjects at the baseline of the study were 1510, consisting of 613 men and 897 women. The results showed that a cumulative incidence of central obesity during the 6-year observation period of $837(55.4 \%)$. Multivariate cox regression analysis showed that the risk factors for central obesity in adults were gender, age group, marital status, and physical activity. This study concluded that female subjects with physical inactivity had more central obesity compared to male subjects with physical inactivity.
\end{abstract}

Keywords: risk factors, central obesity, adults

\section{ABSTRAK}

Obesitas sentral merupakan salah satu masalah kesehatan masyarakat di negara berkembang. Penelitian ini bertujuan untuk menganalisis faktor risiko dinamis terjadinya obesitas sentral pada orang dewasa. Penelitian ini menggunakan data sekunder "Studi Kohor Faktor Risiko Penyakit Tidak Menular (FRPTM)" periode pemantauan selama enam tahun. Desain penelitian adalah kohor prospektif. Subjek adalah semua anggota rumah tangga yang berumur 25 tahun ke atas dengan kriteria tetap tinggal di wilayah penelitian, sehat, tidak cacat fisik, subjek perempuan tidak hamil, memiliki lingkar perut normal (laki-laki $\leq 90 \mathrm{~cm}$ dan perempuan $\leq 80 \mathrm{~cm}$ ) pada awal studi, tidak menderita penyakit tidak menular (hipertensi, diabetes mellitus, kanker, strok, PPOK) pada awal studi, dan kelengkapan data. Jumlah subjek pada awal penelitian 1510 orang, yang terdiri dari 613 laki-laki dan 897 perempuan. Hasil penelitian menunjukkan kumulatif insiden obesitas sentral selama 6 tahun periode pengamatan sejumlah 837 orang $(55,4 \%)$. Hasil analisis multivariat cox regression menunjukkan bahwa faktor risiko terjadinya obesitas sentral pada orang dewasa adalah jenis kelamin, kelompok umur, status kawin, dan aktivitas fisik. Penelitian ini menyimpulkan bahwa subjek perempuan dengan aktivitas fisik kurang lebih cepat mengalami obesitas sentral dibandingkan subjek laki-laki dengan aktivitas fisik kurang.

Kata kunci: faktor risiko, obesitas sentral, dewasa 


\section{PENDAHULUAN}

$\mathrm{M}$ enurut organisasi kesehatan dunia (WHO), obesitas adalah salah satu masalah kesehatan masyarakat di negara maju maupun negara berkembang. ${ }^{1}$ Data WHO menunjukkan satu dari enam orang dewasa mengalami obesitas. ${ }^{2}$ $\mathrm{Di}$ Indonesia, prevalensi obesitas sentral penduduk umur $\geq 15$ tahun pada tahun 2013 adalah 26,6 persen ${ }^{3}$, lebih tinggi dari prevalensi pada tahun $2007(18,8 \%) .{ }^{4}$ Prevalensi obesitas sentral di Indonesia dari hasil analisis Riset Kesehatan Dasar (Riskesdas) 2013 pada umur 25-65 tahun diketahui sebesar 48,5 persen. ${ }^{5}$ Kemudian pada studi awal penelitian kohor di kota Bogor diketahui bahwa prevalensi obesitas sentral sebesar 51,3 persen. ${ }^{6}$

Obesitas sentral berhubungan dengan semua penyebab kematian ${ }^{7,8}$, kesakitan ${ }^{9}$ dan kecacatan yang mengakibatkan usia hidup tidak sehat dengan kualitas hidup yang buruk ${ }^{10}$ serta peningkatan biaya perawatan kesehatan. ${ }^{11,12}$ Beberapa penelitian mendapatkan hasil bahwa obesitas sentral dapat memprediksi penyakit sindrom metabolik, diabetes tipe 2, penyakit kardiovaskular, dan mortalitas lebih baik daripada indeks massa tubuh (IMT). ${ }^{13-15}$

Faktor risiko terjadinya obesitas sentral menurut penelitian Raimi et al. (2015) adalah umur, jenis kelamin, kebiasaan merokok, dan kebiasaan minum alkohol. ${ }^{16}$ Penelitian Pradeepa et al. (2015) menemukan bahwa variabel jenis kelamin, status sosial ekonomi, aktivitas fisik yang kurang, wilayah perkotaan, hipertensi, dan penyakit diabetes berhubungan dengan obesitas sentral. ${ }^{17}$ Penelitian sebelumnya yang dilakukan oleh Sardinha et al. (2012) mendapatkan hasil bahwa tingkat pendidikan yang rendah juga ikut berkontribusi secara bermakna terhadap kejadian obesitas sentral. ${ }^{18}$

Penelitian ini merupakan lanjutan analisis sebelumnya dengan penambahan data perkembangan pemantauan faktor risiko dan outcome sampai dengan tahun 2018 (6 tahun periode pengamatan).6,19 Pada penelitian ini bertujuan untuk menganalisis faktor risiko dinamis terhadap terjadinya obesitas sentral pada orang dewasa.

\section{METODE PENELITIAN}

Penelitian ini menggunakan data "Studi Kohor Faktor Risiko Penyakit Tidak Menular (FRPTM)" periode pemantauan selama 6 tahun pengamatan (baseline data 2011-2012 sampai dengan 2017-2018), yang dilaksanakan oleh Pusat Penelitian dan Pengembangan Upaya Kesehatan Masyarakat, Badan Penelitian dan Pengembangan Kesehatan, Kementerian Kesehatan RI. Desain penelitian adalah kohor prospektif.

Populasi dalam penelitian ini adalah semua anggota rumah tangga yang berumur 25 tahun ke atas di 5 kelurahan dari 11 kelurahan di Kecamatan Bogor Tengah, Kota Bogor, yaitu Kebon Kalapa, Babakan Pasar, Babakan, Ciwaringin dan Panaragan. Subjek adalah semua anggota rumah tangga yang berumur 25 tahun ke atas dengan kriteria tetap tinggal di wilayah penelitian (penduduk tetap yang dibuktikan dengan kartu identitas diri/ Kartu Tanda Penduduk), sehat, tidak cacat fisik, subjek perempuan tidak hamil, memiliki kategori lingkar perut kategori normal (laki-laki $\leq 90 \mathrm{~cm}$ dan perempuan $\leq 80 \mathrm{~cm})^{20}$ pada awal studi, tidak menderita penyakit tidak menular (hipertensi, diabetes mellitus, kanker, strok, PPOK) pada awal studi, dan kelengkapan data. Subjek yang memenuhi kriteria inklusi sejumlah 1.510 pada awal penelitian dan pada 6 tahun periode pengamatan sejumlah 1.234. Jumlah ini masih memenuhi kecukupan sampel berdasarkan perhitungan besar sampel, yang mendapatkan jumlah minimal sampel sebesar 892 sampel. ${ }^{21}$

Data yang dianalisis meliputi jenis kelamin, kelompok umur, status kawin, pendidikan, stres, kebiasaan merokok, aktivitas fisik, konsumsi (gula, lemak, natrium), konsumsi karbohidrat, dan konsumsi sayuran dan buah. Faktor risiko dinamis meliputi variabel stres, kebiasaan merokok, aktivitas fisik, konsumsi (gula, lemak, natrium), konsumsi karbohidrat, dan konsumsi sayuran dan buah. Faktor risiko dinamis dianalisis sampai dengan pengamatan tahun ke-5 (60 bulan).

Pengumpulan data sosiodemografi, merokok, dan aktivitas fisik dengan menggunakan kuesioner yang dikembangkan secara khusus untuk studi kohor faktor risiko penyakit tidak menular di Indonesia yang diadopsi dari The WHO STEPS Instrument for 
Non Communicable Diseases Surveillance. ${ }^{22,23}$ Pengukuran variabel aktivitas fisik didasarkan atas perhitungan secara komposit dari jenis dan lama aktivitas (hari per minggu dan menit per hari) termasuk olahraga yang dilakukan. Aktivitas berat maupun olahraga berat mempunyai bobot 8 kali, aktivitas sedang atau olahraga sedang mempunyai bobot 4 kali, aktivitas ringan mempunyai bobot 2 kali. Subjek dikategorikan kurang aktivitas apabila mempunyai total aktivitas kurang dari $600 \mathrm{MET}$ (metabolic equivalent) dalam satu minggu. 24,25 Kebiasaan merokok dengan indeks Brinkman yaitu jumlah batang rokok yang dihisap selama hidup. Kebiasaan merokok dikategorikan menjadi bukan perokok, perokok sedang, dan perokok berat. ${ }^{26}$ Pengukuran variabel stres dengan menanyakan 20 macam pertanyaan yang mengindikasikan seseorang dalam keadaan stres, bila jawaban "ya" diberi nilai $=1$. Hasil pengukuran dikategorikan stres, bila nilai jawaban "ya" $\geq 6=1$. Tidak stres, bila jawaban "ya" $<6=0.27$

Pendidikan berdasarkan pendidikan terakhir yang dijalani subjek, dibagi menjadi dua kategori, yaitu "rendah" bila tidak pernah sekolah sampai dengan tamat SLTP dan "tinggi" bila tamat SMA sampai dengan perguruan tinggi. Pengukuran lingkar perut subjek umur 25-65 tahun menggunakan pita pengukur yang terbuat dari plastik (medline) dengan ketelitian $0,1 \mathrm{~cm}$. Lingkar perut diukur pada titik antara titik batas tepi tulang rusuk paling bawah dan titik ujung lengkung tulang pangkal paha/panggul pada posisi berdiri tegak dan bernapas dengan normal (ekspirasi normal).28 Pada studi ini status obesitas sentral dikategorikan menjadi event bila lingkar perut laki-laki $>90 \mathrm{~cm}$ dan perempuan $>80 \mathrm{~cm}$, sensor bila lingkar perut laki-laki $\leq 90 \mathrm{~cm}$ dan perempuan $\leq 80 \mathrm{~cm}$ sampai dengan pengamatan ke-72 bulan ( 6 tahun).

Pengumpulan data konsumsi makanan dilakukan satu kali dalam satu tahun. Pengumpulan data konsumsi makanan dilakukan dengan wawancara konsumsi makanan dengan metode recall 1x24 jam. Untuk memperkirakan besaran/porsi makanan/minuman yang dikonsumsi subjek, maka digunakan alat bantu foto makanan dan buku kode bahan makanan.29,30

Konsumsi karbohidrat dikategorikan menjadi $\geq 60 \%$ dan $<60 \%$ dari kebutuhan total energi. Konsumsi buah dan sayur dikategorikan $\geq 200$ gram dan <200 gram. ${ }^{31}$ Konsumsi gula, natrium, dan lemak didasarkan pada Permenkes Nomor 30 tahun 2013 tentang pencantuman informasi kandungan gula, garam, dan lemak serta pesan kesehatan untuk pangan olahan dan pangan siap saji. Konsumsi gula, garam, dan lemak adalah gula, garam, lemak yang dikonsumsi oleh subjek. Konsumsi gula dikategorikan menjadi dua, yaitu: $>50$ $\mathrm{g} /$ hari dan $\leq 50 \mathrm{~g} /$ hari, konsumsi natrium, yaitu: $>2000 \mathrm{mg} / \mathrm{hari}$ dan $\leq 2000 \mathrm{mg} / \mathrm{hari}$, konsumsi lemak, yaitu: $>60$ g/hari dan $\leq 60$ g/hari. ${ }^{32}$

Data yang dianalisis adalah kondisi faktor risiko dan kejadian obesitas sentral (event) yang muncul selama enam tahun pengamatan. Sensor adalah kondisi subjek yang tidak atau belum mengalami obesitas sentral pada waktu kejadian ditetapkan. Survival rate obesitas (waktu ketahanan terhadap obesitas) dihitung dengan life table survival analysis.

Analisis univariat dilakukan terhadap kejadian obesitas sentral menurut faktor risiko baseline (awal penelitian). Pada analisis bivariat terhadap kejadian obesitas sentral menurut faktor risiko dinamis (stres, aktivitas fisik, kebiasaan merokok, konsumsi karbohidrat, konsumsi buah dan sayur, konsumsi gula, konsumsi natrium, konsumsi lemak) dan faktor risiko baseline (jenis kelamin, kelompok umur, status kawin, pendidikan). Analisis bivariat yang digunakan adalah cox regression. Kandidat variabel yang masuk dalam analisis multivariat adalah jika memiliki nilai $p<0,25$ pada analisis bivariat. ${ }^{33}$ Analisis multivariat yang digunakan adalah cox regression.

Pertimbangan etik pelaksanaan penelitian diajukan setiap tahun. Pada tahun 2018 telah memperoleh persetujuan etik dari Komisi Etik Penelitian Kesehatan (KEPK), Badan Penelitian dan Pengembangan Kesehatan Kementerian Kesehatan RI dengan nomor: LB.02.01/2/KE.076/2018.

\section{HASIL}

\section{Karakteristik subjek}

Partisipasi subjek selama periode pengamatan dapat dilihat pada Gambar 1. Respon rate subjek selama 6 tahun periode pengamatan sebesar 93 persen. Insiden kumulatif obesitas sentral selama 6 tahun (72 
bulan) periode pengamatan didapatkan sebesar 55,4 persen $(n=837)$ dengan hazard rate sebesar 10 kasus per 1000 orang-tahun. Pada perempuan hazard rate sebesar 16 kasus per 1000 orang-tahun lebih besar dibandingkan pada laki-laki (4 kasus per 1000 orang-tahun).

Tabel 1 menunjukkan pada tahap baseline, subjek perempuan sebesar 59,4 persen lebih banyak dari laki-laki. Sebaran umur terbanyak terdapat pada kelompok umur 45-54 tahun, yaitu 32,1 persen.

Pendidikan rendah (sampai dengan SMP) ditemukan sebesar 59,1 persen. Kondisi stres subjek menurut hasil wawancara kuesioner diketahui sebesar 27,1 persen. Berdasarkan status kawin diketahui bahwa sebagian besar subjek sudah kawin (84,4\%). Subjek yang belum kawin hanya sebesar 7,1 persen. Aktivitas fisik subjek dalam kategori cukup, yaitu sebesar 51,4 persen sedikit di atas subjek dengan aktivitas fisik kurang 48,6 persen. Data kebiasaan merokok menunjukkan bahwa subjek dengan kategori perokok ringan sebesar 20,3 persen dan perokok berat sebesar 15,5 persen. Subjek dengan konsumsi karbohidrat $\geq 60 \%$ total kalori sebesar 46 persen dan subjek dengan konsumsi karbohidrat kurang dari $60 \%$ total kalori sebesar 54 persen. Sebagian besar subjek mengonsumsi sayur dan buah $\geq 200$ gram per hari $(85,6 \%)$. Konsumsi gula subjek > $50 \mathrm{gr} /$ hari diketahui hanya 5,6 persen. Konsumsi natrium $>2000 \mathrm{mg} / \mathrm{hari}$ diketahui sebesar 44,2 persen. Sementara konsumsi lemak > 60 gram/hari sebesar 24,2 persen (Tabel 1).

Dari Tabel 2 menunjukkan bahwa variabel yang masuk dalam tahap analisis multivariat cox regression $(p<0,25)$ adalah jenis kelamin, kelompok umur, status kawin, aktivitas fisik, kebiasaan merokok, konsumsi sayur dan buah, dan konsumsi gula.

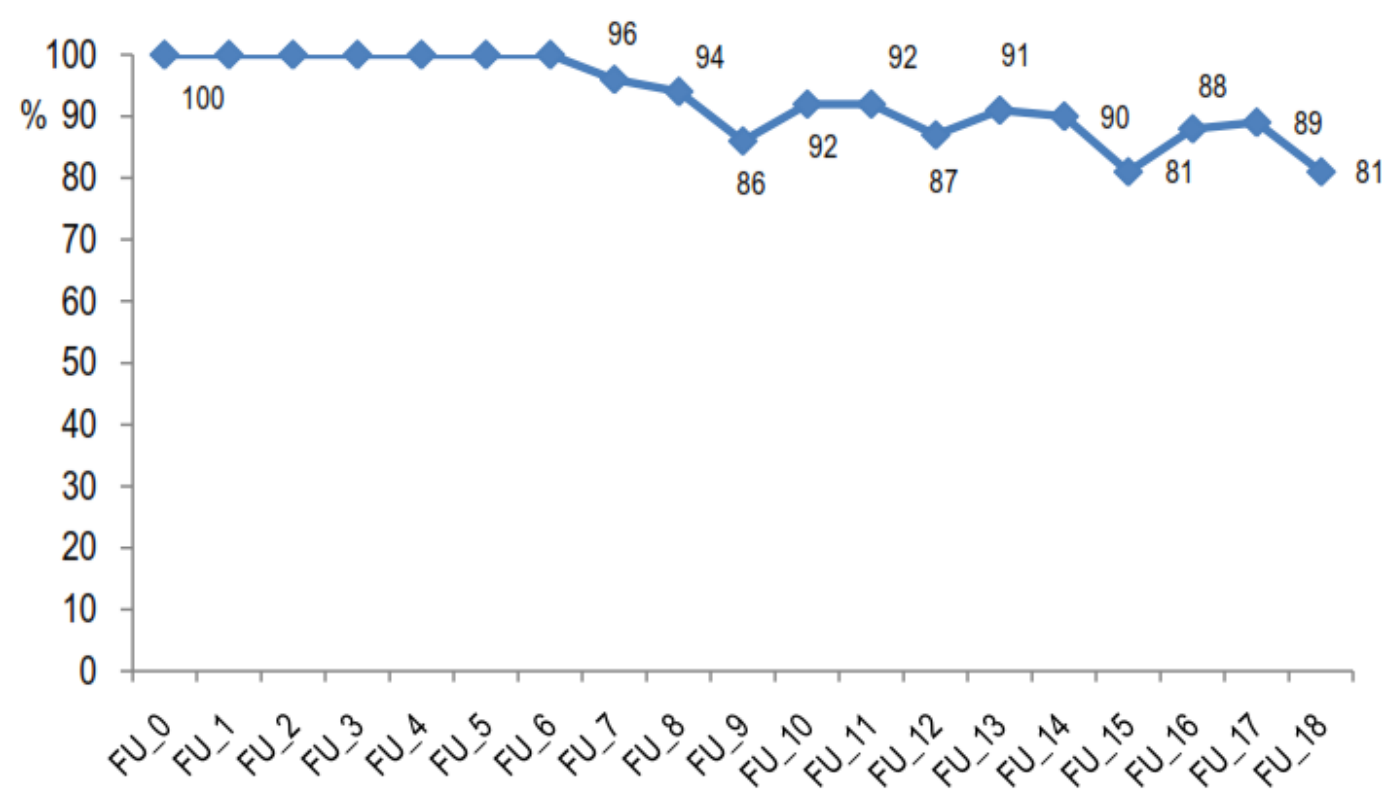

Gambar 1

Persentase Partisipasi Kehadiran Subjek selama Pemantauan 6 tahun 
Tabel 1

Distribusi Responden menurut Karakteristik Sosiodemografi, Kebiasaan Merokok, dan Konsumsi Makanan pada Saat Baseline

\begin{tabular}{|c|c|c|}
\hline Karakteristik & $n=1510$ & $\%$ \\
\hline \multicolumn{3}{|l|}{ Jenis kelamin } \\
\hline - Laki-laki & 613 & 40,6 \\
\hline - Perempuan & 897 & 59,4 \\
\hline \multicolumn{3}{|l|}{ Kelompok umur (tahun) } \\
\hline$-\quad 25-34$ & 302 & 20,0 \\
\hline$-\quad 35-44$ & 460 & 30,5 \\
\hline$-\quad 45-54$ & 484 & 32,1 \\
\hline$-\quad 55+$ & 264 & 17,4 \\
\hline \multicolumn{3}{|l|}{ Pendidikan } \\
\hline - Rendah & 892 & 59,1 \\
\hline - $\quad$ Tinggi & 618 & 40,9 \\
\hline \multicolumn{3}{|l|}{ Status kawin } \\
\hline - Belum kawin & 107 & 7,1 \\
\hline - Kawin & 1275 & 84,4 \\
\hline - Cerai & 128 & 8,5 \\
\hline \multicolumn{3}{|l|}{ Stres } \\
\hline - Tidak & 1101 & 72,9 \\
\hline$-Y a$ & 409 & 27,1 \\
\hline \multicolumn{3}{|l|}{ Aktivitas fisik } \\
\hline - Cukup & 776 & 51,4 \\
\hline - Kurang & 734 & 48,6 \\
\hline \multicolumn{3}{|l|}{ Kebiasaan merokok } \\
\hline - Bukan perokok & 970 & 64,2 \\
\hline - Perokok ringan & 306 & 20,3 \\
\hline - Perokok berat & 234 & 15,5 \\
\hline \multicolumn{3}{|l|}{ Konsumsi karbohidrat } \\
\hline$-\quad<60 \%$ & 816 & 54,0 \\
\hline$-\quad \geq 60 \%$ & 694 & 46,0 \\
\hline \multicolumn{3}{|l|}{ Konsumsi sayur dan buah } \\
\hline$-\quad \geq 200$ gram/hari & 1292 & 85,6 \\
\hline - $<200$ gram/hari & 218 & 14,4 \\
\hline \multicolumn{3}{|l|}{ Konsumsi gula } \\
\hline$-\quad \leq 50 \mathrm{~g} / \mathrm{hari}$ & 1426 & 94,4 \\
\hline$-\quad>50$ g/hari & 84 & 5,6 \\
\hline \multicolumn{3}{|l|}{ Konsumsi natrium } \\
\hline$-\quad \leq 2000$ mghari & 842 & 55,8 \\
\hline _ $>2000 \mathrm{mg} / \mathrm{hari}$ & 668 & 44,2 \\
\hline \multicolumn{3}{|l|}{ Konsumsi lemak } \\
\hline$-\quad \leq 60 \mathrm{~g} / \mathrm{hari}$ & 1145 & 75,8 \\
\hline$-\quad>60$ g/hari & 365 & 24,2 \\
\hline
\end{tabular}


Tabel 2

Hazard Rate Faktor Risiko Obesitas Sentral pada Orang Dewasa Umur 25-65 Tahun

\begin{tabular}{|c|c|c|}
\hline Faktor risiko & $p$ & $\mathrm{HR}(95 \% \mathrm{Cl})$ \\
\hline \multicolumn{3}{|l|}{ Jenis kelamin } \\
\hline - Laki-laki & & 1 \\
\hline - Perempuan & 0,000 & $4,89(4,08-5,85)$ \\
\hline \multicolumn{3}{|l|}{ Kelompok umur (tahun) } \\
\hline$-25-34$ & & 1 \\
\hline$-\quad 35-44$ & 0,054 & $1,21(0,99-1,47)$ \\
\hline$-\quad 45-54$ & 0,096 & $1,18(0,97-1,43)$ \\
\hline$-55+$ & 0,937 & $0,99(0,78-1,24)$ \\
\hline \multicolumn{3}{|l|}{ Pendidikan } \\
\hline - Rendah & & 1 \\
\hline - Tinggi & 0,555 & $0,95(0,83-1,10)$ \\
\hline \multicolumn{3}{|l|}{ Status kawin } \\
\hline - Belum kawin & & \\
\hline - Kawin & 0,000 & $2,32(1,62-3,33)$ \\
\hline - Cerai & 0,000 & $3,16(2,10-4,77)$ \\
\hline \multicolumn{3}{|l|}{ Stres } \\
\hline - Tidak & & 1 \\
\hline$-Y a$ & 0,478 & $1,44(0,52-3,97)$ \\
\hline \multicolumn{3}{|l|}{ Aktivitas fisik } \\
\hline - Cukup & & 1 \\
\hline - Kurang & 0,000 & $0,75(0,64-0,87)$ \\
\hline \multicolumn{3}{|l|}{ Kebiasaan merokok } \\
\hline - Bukan perokok & & 1 \\
\hline - Perokok ringan & 0,000 & $0,38(0,31-0,46)$ \\
\hline - Perokok berat & 0,000 & $0,24(0,11-0,50)$ \\
\hline \multicolumn{3}{|l|}{ Konsumsi karbohidrat } \\
\hline$-<60 \%$ & & 1 \\
\hline$-\quad \geq 60 \%$ & 0,058 & $0,83(0,69-1,00)$ \\
\hline \multicolumn{3}{|l|}{ Konsumsi sayur dan buah } \\
\hline$-\quad \geq 200$ gram & & 1 \\
\hline$-\quad<200$ gram & 0,035 & $1,20(1,01-1,43)$ \\
\hline \multicolumn{3}{|l|}{ Konsumsi gula } \\
\hline$-\quad \leq 50 \mathrm{~g} / \mathrm{hari}$ & & 1 \\
\hline$-\quad>50$ g/hari & 0,000 & $0,43(0,30-0,61)$ \\
\hline \multicolumn{3}{|l|}{ Konsumsi natrium } \\
\hline$-\leq 2000 \mathrm{mg} / \mathrm{hari}$ & & 1 \\
\hline _ $>2000 \mathrm{mg} / \mathrm{hari}$ & 0.426 & $1,05(0,91-1,22)$ \\
\hline \multicolumn{3}{|l|}{ Konsumsi lemak } \\
\hline$-\quad \leq 60 \mathrm{~g} /$ hari & & 1 \\
\hline$-\quad>60$ g/hari & 0.984 & $1,00(0,87-1,15)$ \\
\hline
\end{tabular}

Berdasarkan Tabel 3 dapat diketahui bahwa faktor risiko terjadinya obesitas sentral pada orang dewasa adalah jenis kelamin, kelompok umur, status kawin, dan aktivitas fisik. Subjek perempuan mempunyai hazard ratio (HR) 5,57 kali lebih cepat $(95 \% \mathrm{Cl}: 4,56-6,81)$ 
untuk menjadi obesitas sentral dibandingkan subjek laki-laki setelah dikontrol oleh variabel kelompok umur, status kawin, dan aktivitas fisik. Subjek pada kelompok umur 35-44 dan kelompok umur 45-54 masing-masing memiliki hazard ratio 1,25 dan 1,34 kali lebih cepat untuk mengalami obesitas sentral dibandingkan subjek pada kelompok umur 25-34 tahun setelah dikontrol variabel jenis kelamin, status kawin, dan aktivitas fisik. Subjek dengan status kawin dan cerai masing-masing memiliki hazard ratio 1,63 dan 1,66 kali lebih cepat untuk mengalami obesitas sentral dibandingkan subjek yang belum kawin setelah dikontrol variabel jenis kelamin, kelompok umur, dan aktivitas fisik. Subjek dengan aktivitas fisik kurang mempunyai hazard ratio (HR) 1,2 kali lebih cepat $(95 \% \mathrm{Cl}: 1,01-1,39)$ untuk menjadi obesitas sentral dibandingkan subjek dengan aktivitas fisik cukup setelah dikontrol variabel jenis kelamin, kelompok umur, dan status kawin. Enam tahun survival rate pada subjek perempuan dengan aktivitas fisik kurang untuk mengalami obesitas sentral sebesar 21,5 persen, sementara survival rate pada subjek laki-laki dengan aktivitas fisik kurang sebesar 72,5 persen. Pada pengamatan bulan ke-26 subjek perempuan dengan aktifitas fisik kurang sudah mengalami obesitas sentral, sementara subjek laki-laki dengan aktivitas fisik kurang kejadian obesitas sentral didapatkan pada pengamatan bulan ke-57 (Tabel 4). Secara rinci penurunan survival rate pada subjek perempuan selama 6 tahun periode pengamatan dapat dilihat pada Gambar 2.

Tabel 3

Model Akhir Analisis Multivariat Cox Regression Faktor Risiko Obesitas Sentral pada Orang Dewasa Umur 25-65 Tahun

\begin{tabular}{lrrr}
\hline Faktor risiko & $p$ & $\mathrm{HR}$ & $95 \% \mathrm{Cl}$ \\
\hline $\begin{array}{c}\text { Jenis kelamin } \\
\text { Laki-laki } \\
\text { Perempuan }\end{array}$ & & 1 & \\
$\begin{array}{c}\text { Kelompok umur (tahun) } \\
25-34\end{array}$ & 0,000 & 5,53 & $4,51-6,78$ \\
$35-44$ & & 1 & \\
$45-54$ & 0,033 & 1,25 & $1,01-1,54$ \\
$55+$ & 0,005 & 1,34 & $1,09-1,66$ \\
Status kawin & 0,141 & 1,20 & $0,94-1,53$ \\
Belum kawin & & & \\
Kawin & 0,016 & 1,63 & $1,09-2,42$ \\
Cerai & 0,027 & 1,66 & $1,05-2,61$ \\
Aktivitas fisik & & & \\
Cukup & 0,019 & 1,20 & $1,03-1,41$ \\
Kurang & & &
\end{tabular}

Tabel 4

Survival Rate Faktor Risiko Obesitas menurut Aktivitas fisik dan Jenis Kelamin

\begin{tabular}{llcc}
\hline Faktor risiko & & $\begin{array}{c}\text { Mean } \\
\text { (bulan) }\end{array}$ & $\begin{array}{c}\text { Survival rate } \\
(\%)\end{array}$ \\
\hline Aktivitas fisik pada laki-laki & Cukup & 63 & 82,5 \\
& Kurang & 57 & 72,5 \\
Aktivitas fisik pada perempuan & Cukup & 29 & 23,1 \\
& Kurang & 26 & 21,5 \\
\hline
\end{tabular}



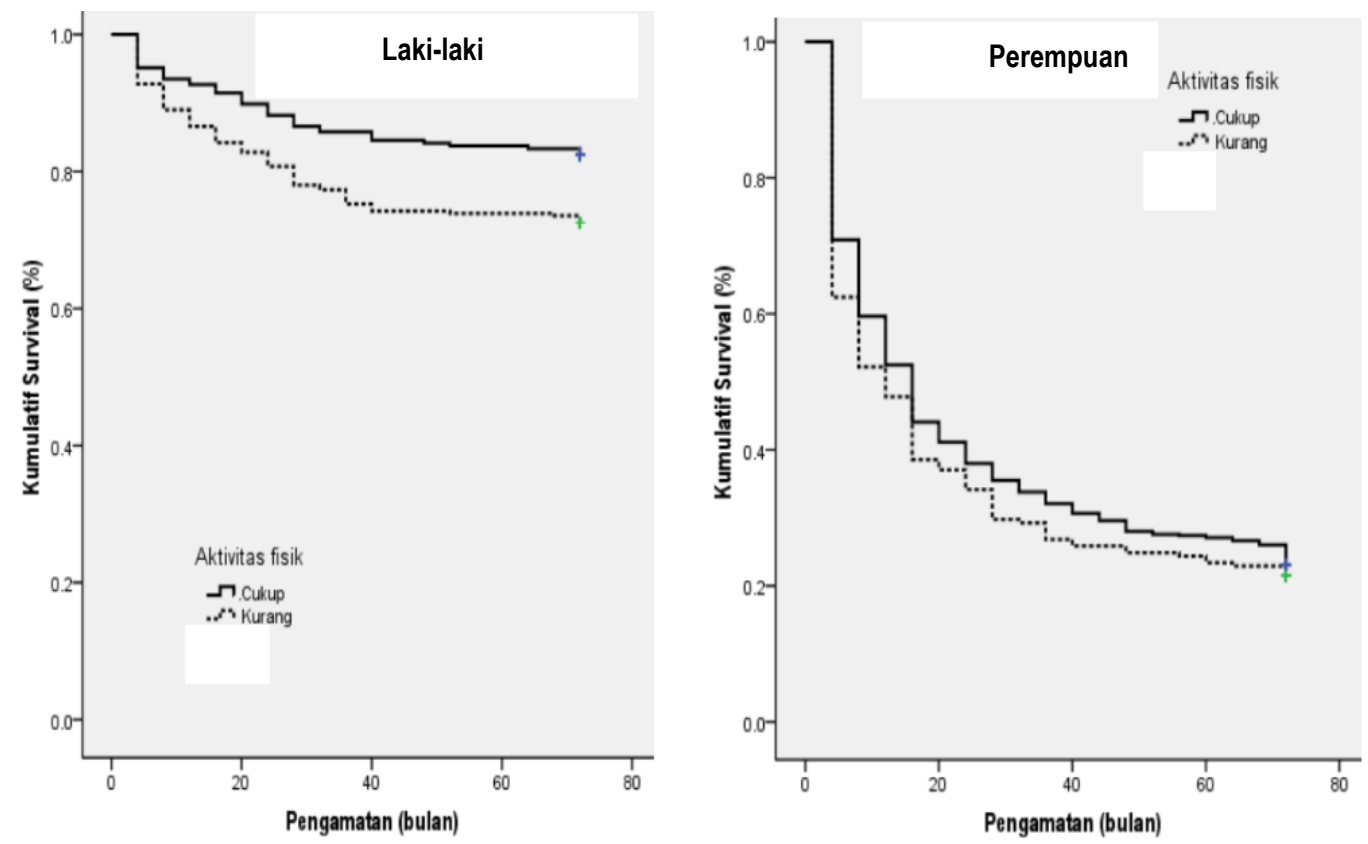

Gambar 2

Kumulatif Survival Risiko Terjadinya Obesitas Sentral menurut Aktivitas Fisik pada Laki-laki dan Perempuan

\section{BAHASAN}

Pada penelitian ini menunjukkan bahwa subjek perempuan mempunyai hazard ratio 5,53 kali lebih cepat untuk mengalami obesitas sentral dibandingkan dengan laki-laki. Pada penelitian Raimi et al. (2015) ${ }^{34}$, Pradeepa et al. (2015) ${ }^{17}$; Chukwuonye et al. (2013) ${ }^{35}$, Oladapo et al. $(2010)^{36}$, Adediran et al. $(2012)^{37}$, lloh et al. (2011) $)^{38}$, Adienbo et al. (2012) ${ }^{39}$, juga mendapatkan hasil bahwa kejadian obesitas sentral pada perempuan lebih tinggi dibandingkan dengan laki-laki.

Menurut kelompok umur, pada hasil penelitian ini menunjukkan bahwa hazard ratio obesitas sentral pada kelompok umur 35-44 tahun dan kelompok umur 45-54 tahun lebih cepat terjadi obesitas sentral dibandingkan dengan kelompok umur 25-34 tahun, walaupun pada kelompok umur 55 ke atas menunjukkan penurunan hazard ratio untuk terjadinya obesitas sentral. Hasil yang sama ditunjukkan oleh penelitian Raimi et al. (2015). ${ }^{34}$ Penuaan dikaitkan dengan perubahan komposisi tubuh yang mengakibatkan peningkatan massa lemak dan penurunan massa otot. ${ }^{40}$

Berdasarkan status kawin, pada penelitian ini menunjukkan bahwa subjek dengan status kawin dan subjek dengan status cerai lebih cepat terjadi obesitas sentral dibandingkan dengan subjek yang belum kawin. Hasil penelitian Sugianti (2009) juga menunjukkan adanya hubungan antara status kawin pada subjek penelitian dengan kejadian obesitas sentral dibandingkan subjek yang belum kawin. ${ }^{41}$

Pada penelitian ini juga mendapatkan hasil bahwa subjek dengan aktivitas fisik kurang memiliki hazard ratio 1,2 kali lebih cepat untuk mengalami obesitas sentral dibandingkan subjek dengan aktivitas fisik yang cukup. Beberapa penelitian tentang aktivitas fisik dan kejadian obesitas menunjukkan bahwa subjek dengan aktivitas fisik kurang memiliki risiko obesitas sebesar 1.04 kali (Cl 95\%: 0.84-1.03) dibandingkan dengan subjek dengan aktivitas fisik yang dianjurkan. Laki-laki dengan aktivitas fisik kurang mempunyai risiko obesitas sebesar 1.39 kali (Cl 95\%: 1.02-1.89), sedangkan perempuan dengan aktivitas fisik kurang mempunyai risiko obesitas sebesar 1.28 kali $(\mathrm{Cl}$ 95\%: 0.99-1.65).42 Hasil yang sama juga terdapat pada penelitian Kaplan et al. (2003) yang menyatakan bahwa aktivitas fisik kurang terkait dengan obesitas. Subjek dengan aktivitas fisik kurang memiliki risiko obesitas sebesar 2.13 kali (Cl 95\%: 1.81-2.50) dibandingkan dengan subjek dengan aktivitas 
fisik cukup. Risiko ini cukup besar, baik pada laki-laki maupun perempuan. Risiko obesitas pada laki-laki dengan aktivitas fisik kurang sebesar 2.49 kali (Cl 95\%: 1.65-3.75) dibandingkan dengan laki-laki dengan aktivitas fisik cukup. Risiko obesitas pada perempuan dengan aktivitas fisik kurang sebesar 1.85 kali (Cl 95\%: 1.65-2.07) dibandingkan dengan perempuan dengan aktivitas fisik cukup. ${ }^{43}$

Menurut WHO (2010), aktivitas fisik secara konsisten terkait dengan faktor individu seperti umur, jenis kelamin, status kesehatan, selfefficacy, dan aktivitas fisik sebelumnya. ${ }^{24}$ Kemajuan teknologi, yang ditunjang oleh perangkat hemat tenaga dan bentuk hiburan elektronik yang mudah didapatkan dan digunakan selama waktu senggang membutuhkan pengeluaran energi lebih sedikit dalam pengaturan kerja di rumah tangga maupun di kantor, sehingga hal ini meminimalkan kegiatan fisik. ${ }^{44,45}$ Pengeluaran energi melalui aktivitas fisik merupakan bagian yang penting dalam rangka menyeimbangkan energi yang menentukan berat badan. WHO (2003) menyatakan bahwa penurunan energy expenditure melalui pengurangan aktivitas fisik memicu terjadinya kegemukan dan obesitas. ${ }^{46}$ Kurangnya waktu secara konsisten sebagai kendala utama dalam menjamin aktivitas fisik yang cukup. ${ }^{44}$ Australian Government Independent Sports Panel (2009) mendapatkan adanya korelasi yang kuat antara partisipasi olahraga dan pendapatan keluarga. Biaya berpartisipasi dalam aktivitas fisik atau olahraga semakin berat bagi orang dengan banyak keluarga. ${ }^{47}$

Menurut Kementerian Kesehatan (2014) bahwa melakukan aktivitas fisik yang cukup dan mempertahankan berat badan normal adalah salah satu upaya untuk mencegah terjadinya obesitas sentral. Aktivitas fisik dikategorikan cukup apabila seseorang melakukan latihan fisik atau olah raga selama 30 menit setiap hari atau minimal 3-5 hari dalam seminggu. Beberapa aktivitas fisik yang dapat dilakukan antara lain aktivitas fisik sehari-hari seperti berjalan kaki, berkebun, menyapu, mencuci, mengepel, naik turun tangga dan lain-lain. ${ }^{31} \mathrm{Di}$ samping itu, untuk meningkatkan kesehatan dan kebugaran perlu dikembangkan juga olahraga rekreasi yang dilakukan oleh masyarakat dengan kegemaran sesuai dengan kondisi dan nilai budaya masyarakat sehingga menimbulkan kegembiraan. Olahraga rekreasi yang dilakukan oleh masyarakat yang tumbuh dan berkembang sesuai kondisi dan nilai budaya masyarakat setempat perlu didorong untuk mencapai kebutuhan aktivitas fisik yang optimal. Berikut beberapa contoh budaya tradisional yang dapat dijadikan sebagai aktivitas fisik: Tari Poco-Poco dari Papua, Tari Bambu dari Maluku, Tari Jaipong dari Jawa Barat, Tari Saman dari Aceh, Tari Kecak dari Bali, dll. ${ }^{48}$

Pada penelitian ini belum membuktikan adanya hubungan antara konsumsi makanan dengan obesitas sentral. Hal ini kemungkinan karena konsumsi makanan pada subjek diambil hanya satu kali dalam satu tahun, sehingga kurang menggambarkan kondisi sebenarnya konsumsi subjek, baik dari jenis maupun jumlah makanan yang dikonsumsi. Penambahan pengukuran konsumsi makanan pada subjek lebih dari satu kali dalam satu tahun dengan waktu yang tidak berurutan akan lebih menguatkan hasil penelitian berikutnya.

\section{SIMPULAN DAN SARAN}

\section{Simpulan}

Faktor risiko terjadinya obesitas sentral pada orang dewasa selama 6 tahun periode pengamatan adalah: jenis kelamin, kelompok umur, status kawin, dan aktivitas fisik. Subjek perempuan dengan aktivitas fisik kurang lebih cepat mengalami obesitas sentral dibandingkan subjek laki-laki dengan aktivitas fisik kurang.

\section{Saran}

Pencegahan obesitas sentral pada orang dewasa melalui pemenuhan aktivitas fisik yang cukup dan mempertahankan berat badan normal. Olahraga rekreasi yang dikembangkan oleh masyarakat diharapkan dapat mencapai aktivitas fisik yang optimal.

\section{UCAPAN TERIMA KASIH}

Ucapan terima kasih disampaikan kepada enumerator, tim studi kohor faktor risiko penyakit tidak menular, Kepala Badan Penelitian dan Pengembangan Kesehatan, dan tim manajemen data Balitbangkes Kemenkes RI. 


\section{RUJUKAN}

1. World Health Organization (WHO). 2000. Obesity: Preventing and Managing the Global Epidemic. Report of a WHO Consultation. Geneva: WHO.

2. World Health Organization. 2012. World Health statistics. 2012. Geneva: WHO.

3. Kementerian Kesehatan. 2014. Riskesdas 2013. Jakarta (ID): Badan Litbang Kesehatan

4. Departemen Kesehatan RI. 2008. Laporan Hasil Riset Kesehatan Dasar Tahun 2007. Jakarta (ID): Depkes RI.

5. Sudikno, Syarief $H$, Dwiriani $C M$, Riyadi $H$. 2015. Faktor risiko overweight dan obese pada orang dewasa di Indonesia. (Analisis data Riset Kesehatan Dasar 2013). Gizi Indon. 38(2):91-104.

6. Sudikno, Syarief $\mathrm{H}$, Dwiriani $\mathrm{CM}$, Riyadi $\mathrm{H}$, Pradono J. 2016. Hubungan Obesitas Sentral dengan Profil Lipid pada Orang Dewasa Umur 25-65 tahun di Kota Bogor (Baseline Studi Penyakit Tidak Menular di Kota Bogor, Jawa Barat). Gizi Indon. 39(2):81-92.

7. Cameron AJ, Magliano DJ, Shaw JE, Zimmet PZ, Carstensen B, Alberti KGMM, Tuomilehto J, Barr ELM, Pauvaday VK, Kowlessur S et al. 2012. The influence of hip circumference on the relationship between abdominal obesity and mortality. Int $J$ Epidemiol. 41: 484-494. doi:10.1093/ije/dyr198.

8. Whitlock $G$, Lewington $S$, Sherliker $P$, Clarke R, Emberson J, Halsey J, Qizilbash N, Collins R, Peto R. 2009. Body-mass index and cause-specific mortality in 900 000 adults: collaborative analyses of 57 prospective studies. Lancet. 373: 10831096.

9. Grimble RF. 2010. The true cost of inpatient obesity: impact of obesity on inflammatory stress and morbidity. Proc Nutr Soc. 69: 511-517. doi: 10.1017/S0029665110001709.

10. Perez M, Warren CS. 2012. The relationship between quality of life, bingeeating disorder, and obesity status in an ethnically diverse sample. Obesity. 20(4):879-885. doi:10.1038/oby.2011.89.

11. Moriarty JP, Branda ME, Olsen KD, Shah $\mathrm{ND}$, Borah BJ, Wagie AE, Egginton JS,
Naessens JM. 2012. The effects of incremental costs of smoking and obesity on health care costs among adults: a 7year longitudinal study. J Occup Environ Med. 54(3): 286-291. doi: 10.1097/JOM.0b013e318246f1f4.

12. Cawley J, Meyerhoefer C. 2012. The medical care costs of obesity: an instrumental variables approach. $J$ Health Econ. 31: 219-230. doi: 10.1016/j.jhealeco.2011.10.003.

13. Visscher TL, Seidell JC, Molarius A, Van der Kuip D, Hofman A, Witteman JC. 2001. A comparison of body mass index, waisthip ratio and waist circumference as predictors of all-cause mortality among the elderly: the Rotterdam study. Int. J. Obes. Relat. Metab. Disord. 25(11):1730-1735.

14. Despre's JP, Lemieux I, Bergeron J, Pibarot $P$, Mathieu $P$, Larose E, Rode'sCabau J, Bertrand OF, Poirier P. 2008. Abdominal Obesity and the Metabolic Syndrome: Contribution to Global Cardiometabolic Risk. Arterioscler Thromb Vasc Biol. 28:1039-1049.

15. Goh LGH, Dhaliwal SS, Welborn TA, Lee AH, Della PR. 2014. Ethnicity and the association between anthropometric indices of obesity and cardiovascular risk in women: a cross-sectional study. BMJ Open. 4:e004702. doi:10.1136/bmjopen2013-004702.

16. Raimi TH, Odusan O, Fasanmade O. 2015. High prevalence of central obesity in rural South-Western Nigeria: Need for targeted prevention. J. Diabetes Endocrinol. 6(3):1218. doi: 10.5897/JDE2015.0084.

17. Pradeepa R, Anjana RM, Joshi SR, Bhansali A, Deepa M, Joshi PP, Dhandania VK, Madhu SV, Rao PV, Geetha $L$ et al. 2015. Prevalence of Generalized and Abdominal Obesity in Urban and Rural India- the ICMR-INDIAB STUDY (Phase-I) [ICMR-INDIAB-3]. Indian J Med Res. 142:139-150. doi:10.4103/09715916.164234.

18. Sardinha LB, Santos DA, Silva AM, Coelhoe-Silva MJ, Raimundo AM, Moreira $\mathrm{H}$, Santos R, Vale S, Baptista F, Mota J. 2012. Prevalence of Overweight, Obesity, and Abdominal Obesity in a Representative Sample of Portuguese Adults. Plos One. 
7(10):

e47883.

doi:10.1371/journal.pone.0047883.

19. Sudikno. Studi kohor faktor risiko obesitas dan dislipidemia pada orang dewasa umur 25-65 tahun di Kota Bogor. Disertasi. Institut Pertanian Bogor. 2017.

20. World Health Organization. 2008. Waist circumference and waist-hip ratio: report of a WHO expert consultation. Geneva, Switzerland: WHO.

21. Lemeshow S. 1997. Besar Sampel dalam Penelitian Kesehatan (Terjemahan Dibyo Pramono). Yogyakarta: Gajah Mada University Press.

22. Riyadina W, Pradono J, Werdhasari A, Rahajeng $E$, Oemiati $R$, Sirait AM, Sihombing M, Tuminah S, Sapardin AN, Sulistiowati E et al. 2012. Laporan Akhir Penelitian Studi Kohor Tumbuh Kembang Anak dan Faktor Risiko Penyakit Tidak Menular Tahun 2012. Jakarta (ID): Badan Litbangkes Kementerian Kesehatan RI.

23. World Health Organization (WHO). 2001. Summary: Surveillance of risk factors for noncommunicable diseases The WHO STEP wise approach. Geneva: WHO.

24. World Health Organization. 2010, Global recommendations on physical activity for health. Geneva: WHO.

25. World Health Organization. 2011. Global Physical Activity Questionnaire (GPAQ). Geneva: WHO.

26. Rizky Amelia, Ellyza Nasrul, Masrul Basyar. 2016. Hubungan derajat merokok berdasarkan indeks brinkman dengan kadar hemoglobin. Jurnal Kesehatan Andalas. 5(3):619-24.

27. WHO Division of Mental Health. 1994. A User's Guide to The Self Reported Questionnaire (SRQ). Geneva. WHO.

28. Gibson. 1990. Nutritional Assessment. Oxford University.

29. Badan Litbangkes Kemenkes RI. 2014. Buku Pedoman Kode Bahan Makanan Survei Konsumsi Makanan Individu: Studi Diet Total 2014. Jakarta (ID): Badan Litbangkes Kementerian Kesehatan RI.

30. Tim Survei Konsumsi Makanan Individu. 2014. Buku Foto Makanan. Jakarta (ID): Pusat Teknologi Terapan Kesehatan dan Epidemiologi Klinik Badan Litbangkes Kementerian Kesehatan RI.
31. Kementerian Kesehatan RI, Direktorat Jenderal Bina Gizi dan Kesehatan Ibu dan Anak. 2014. Pedoman Gizi Seimbang. Jakarta (ID): Kemenkes RI.

32. Kementerian Kesehatan Republik Indonesia. 2013. Peraturan Menteri Kesehatan Nomor 30 Tahun 2013 tentang Pencantuman Informasi Kandungan Gula, Garam, dan Lemak Serta Pesan Kesehatan Untuk Pangan Olahan dan Pangan Siap Saji (Berita Negara Republik Indonesia Tahun 2013 Nomor 617). Jakarta (ID): Kemenkes RI.

33. Hosmer DW, Lemeshow S. 2000. Apllied Logistic Regression: second edition. New York (ID): John Wiley \& Sons.

34. Raimi TH, Odusan O, Fasanmade O. 2015. High prevalence of central obesity in rural South-Western Nigeria: Need for targeted prevention. J. Diabetes Endocrinol. 6(3):1218. doi: 10.5897/JDE2015.0084.

35. Chukwuonye II, Chuku A, Onyeonoro UU, Okpechi IG, Madukwe TI, Ogah OS. 2013. Prevalence of abdominal obesity in Abia State, Nigeria: results of a populationbased house-to-house survey. Diabetes Metab. Syndr. Obes. 6:285-291.

36. Oladapo OO, Falase AO, Salako L, Sodiq O, Soyinka K, Adedapo K. 2010. Prevalence of cardiometabolic risk factore among a rural Yoruba south-western Nigerian population: a population- based survey. Cardiovasc. J. Afr. 21(1):26-31.

37. Adediran OS, Okpara IC, Adeniyi OS, Jimoh AK. 2012. Obesity prevalence and its associated factors in an urban and rural area of Abuja, Nigeria. Glo Adv. Res. J. Med. Med. Sci. 1(8):237-241.

38. Iloh G, Amadi AN, Nwankwo BO, Ugwu VC. 2011. Obesity in adult Nigerians: A study of its pattern and common primary comorbidities in a rural Mission General Hospital in Imo state, South-Eastern Nigeria. Niger. J. Clin. Pract. 14(2):212218. doi: 10.4103/1119-3077.84019.

39. Adienbo OM, Hart VO, Oyeyemi WA. 2012. High prevalence of obesity among indigenous residents of a Nigerian ethnic group: The Kalabaris in the Niger Delta region of South-Southern Nigeria. Greener J. Med. Sci. 2(6):152-156.

40. Hughes VA, Frontera WR, Roubenoff $R$, Evan WJ, Singh MA. 2002. Longitudinal 
changes in body composition in older men and women: role of body weight change and physical activity. Am. J. Clin. Nutr. 76(2):473-481.

41. Sugianti $E$, Hardinsyah, Afriansyah $N$. 2009. Faktor Risiko Obesitas Sentral pada Orang Dewasa di DKI Jakarta: Analisis Lanjut Data Riskesdas 2007. Gizi Indon. 32(2):105-116.

42. Kruger J, Ham SA, Prohaska TR. 2009. Behavioral Risk Factors Associated With Overweight and Obesity Among Older Adults: the 2005 National Health Interview Survey. Preventing Chronic Disease, Public Health Research, Practice and Policy. 6(1):1-17.

43. Kaplan MS, Huguet N, Newsom JT, McFarland BH, Lindsay J. 2003. Prevalence and Correlates of Overweight and Obesity Among Older Adults: Finding From the Canadian National Population Health Survey. Journal of Gerontology: Medical Sciences. 8A(11): 1018-1030.
44. Bauman A, Bellew B, Vita P, Brown W, Owen N. 2002. Getting Australia active: towards better practice for the promotion of physical activity. Melbourne: National Public Health Partnership.

45. Edwards P, Tsouros A. 2006. The Solid Facts: Promoting physical activity and active living in urban environments: The Role of Local Governments. Geneva: WHO European Office.

46. World Health Organization. 2003. Diet, Nutrition and Prevention of Chronic Disease. WHO Technical Report Series No.916. Geneva: WHO.

47. Australian Government Independent Sports Panel. 2009. The future of sport in Australia. Canberra: Commonwealth of Australia.

48. Kementerian Kesehatan. Direktorat Bina Kesehatan Kerja dan Olahraga, Ditjen Bina Gizi dan KIA. 2012. Peningkatan Kebugaran Jasmani di Tempat Kerja. Jakarta (ID): Kemenkes RI. 